\author{
DEPARTMENT OF THE INTERIOR \\ UNITED STATES GEOLOGICAL SURVEY
}

PREPARED IN COOPERATION WITH THE

DIVISION OF BIOLOGY AND MEDICINE

U.S. ATOMIC ENERGY COMMISSION

\title{
NATURAL GAMMA AERORADIOACTIVITY OF PARTS OF THE LOS ANGELES REGION, CALIFORNIA \\ By
}

K. G. Books

1962

GEOPHYSICAL INVESTIGATIONS
MAP GP-309

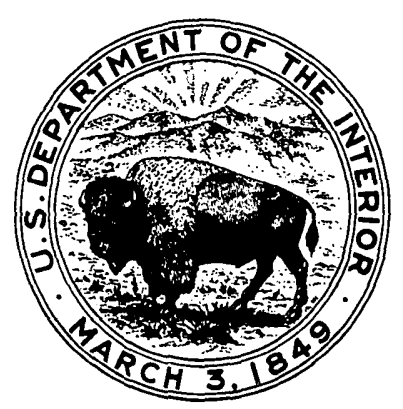

PUBLISHED BY THE U. S. GEOLOGICAL SURVEY WASHINGTON, D.C. 